\title{
Quality measurers of therapeutic communities for substance dependence: an international collaborative study survey in Latin America
}

Carlos Gómez-Restrepo ${ }^{1 *}$ D, Patricia Maldonado², Nelcy Rodríguez', Rafael Ruiz-Gaviria', Miguel Ángel Escalante ${ }^{3}$, Raúl Ángel Gómez ${ }^{3}$, Marcelo Ribeiro de Araujo ${ }^{4}$, Ana Carolina Schmidt de Oliveira ${ }^{4}$, Joel Salvador Chávez Rivera ${ }^{5}$, Jorge Alberto Godínez García ${ }^{6}$, Marina Piazza Ferrand ${ }^{7}$ and Dora Blitchtein-Winicki ${ }^{8}$

\begin{abstract}
Background: In Latin America, substance related disorders are highly prevalent and one of the treatment strategies is the Therapeutic Communities (TCs), however, in Latin America there is scarce data about this treatment strategies, their quality, drop-out rates and patient satisfaction.

Methods: Based on a previous study in 5 Latin American countries, the TCs who had a score equal or higher than 9 according to the De Leon criteria which are some fundamental items that the TCs should meet, were selected to carry out a descriptive and retrospective study of qualitative and quantitative characteristics of the TCs.

Results: Data from 58 TCs in 5 countries were included, with a sample of 1414 patients interviewed, of which most were single men, with no hospitalization history in a therapeutic community. Marijuana was the most commonly substance used in the 30 days prior to hospitalization, with $78 \%$ of interviewees referring alcohol consumption in the last 6 months and an average onset of psychoactive substances at 16 years of age. A 79\% of the patients interviewed perceived some improvement during their stay in the TCs. The less fulfilled Quality Indicators by the TCs were "Requesting a professional qualification to former addicts that belonged to the program" and "Work as part of the therapeutic program". Among the reasons for discharge found in the database, $44 \%$ were due to therapeutic discharge with fulfillment of the treatment plan and $44 \%$ withdraws.
\end{abstract}

Conclusion: The user satisfaction with TCs, in terms of infrastructure and quality are quite high, as the fulfillment of essential quality items, however, the follow up information to evaluate effectiveness of the treatment is poor or in some cases unknown.

Keywords: Therapeutic communities (TCs), Substance-related disorders, Patient satisfaction, Patient compliance

\section{Background}

Use of psychoactive substances (PSs) is one of the psychiatric disorders that has generated great interest from governments because of the economic, political, social and health implications of their consumption [1-3]. Chronic use of these substances generates molecular and cellular changes that will effect in behavioral and lifestyle

\footnotetext{
* Correspondence: cgomez_restrepo@yahoo.com

'Department of Clinical Epidemiology and Biostatistics, Hospital Universitario

San Ignacio, Pontificia Universidad Javeriana, Bogota, Colombia

Full list of author information is available at the end of the article
}

alterations that affect the individual suffering from such diseases [4]. In addition, use of PSs, is accompanied by increased risk behaviors, traffic accidents and co-infection with diseases like HIV and Hepatitis $C$ virus $[1,5,6]$.

In a study conducted by the World Health Organization (WHO)with several countries in different regions of the world, including Europe and the Americas, evaluating the prevalence of alcohol use disorders or other psychoactive substances in the past 12 months, a prevalence from $5.8 \%$ in Mexico to 13.2 in Germany [7] was found. The prevalence of such pathologies is not a 
negligible value taking into account the consumption of any substance, if we review that the substance use disorder accounted for 0.5 of the total years of life lost (YLL) worldwide, emphasizing that the most affected population is in the age group between 15 and 30 years [8] (6).

Nowadays the management and support of patients with substance use disorders are very wide but their objective is helping them to avoid use of the substance and abandon drug seeking behaviors. Despite the treatment and commitment of the patient to the management, research has shown relapse rates of up to 40 or $50 \%$, so the treatment has to be done in more than one occasion [9].

One of the treatmen or management options are the TCs. These are self-help programs for abandonment of harmful substance use behaviours and health recovery of the patient through an individual personal growth, that is performed separating the subject from society and submitting the patients in a specific community with professional staff and other patients with substance use $[10,11]$.

TCs have proven to be effective in helping the patients abandon the active consumption of the substance, returning to their jobs, improving mental health and quality of life and also increasing the time to relapse and drug-free periods [12-15].

In the longest study conducted by the National Institue of Drug Abuse (NIDA), the DATOS study (Drug Abuse Treatment Outcome Studies) included more than 10,000 patients and compared the effectiveness of different therapeutic options for substance use, including TCs. The study showed that in those patients treated with this modality there was a reduction of heroin, cocaine and alcohol use after 1 and 5 years of fulfilling the treatment. Besides, this study also showed increased patient employment rates after the end of the treatment, proving through different outcomes measures the effectiveness of the TCs [16].Despite that some studies have shown the impact of the TCs, not all the TCs fulfil the quality standards recommended by the World Federation of Therapeutic Communities (WFTC). This variability can explain the different in the success and relapses rates [14].

Studies of the amount, quality and need of the TCs has been done mostly in USA [16] and Europe [17]. very few studies have been conducted in Latin America that identify and describe the characteristics of the people attending these facilities, the pattern of substance use, satisfaction and perceived effectiveness of these treatments by users, and the follow up of the patients who fulfilled the therapeutic plan.

In a previous study conducted in Latin America by the same authors and in collaboration with Latin American Federation of Therapeutic Communities (LAFCT) that identified the TCs, available and their respective quality in Argentina, Brazil, Colombia, Mexico and Peru. Using the database of the available TCs obtained in that study it is intended to identify the sociodemographic variables, consumption patterns, user perception of effectiveness, fulfillment of the treatment plan and follow up of the users in the same 5 countries that provided the database of the TCs.

\section{Methods}

Based on the study conducted in 2013 which identified all the available TCs who accepted to participate and answered a questionnaire about their structure, therapeutic plans and were evaluated according to the De Leon criteria(These are 12 essential items established by a group of authors that should be accomplished in order to deliver quality care to the users) $[18,19]$. The TCs that obtained a score equal or higher than 9 points according to De Leon criteria were selected (See Table 1). TCs were excluded if they exclusively worked as an outpatient basis or whose target patients was exclusively minors or took care of fewer than 50 patients or if their therapeutic plan was less than 30 days. Once the sample of TCs that fulfilled the selection criteria and were willing to participate was established, a random number was generated considering a simple distribution. With the subsequent setup of the TCs in a list and then selecting TCs from each country.

Once selected the TCs in each country, visits were made to each of them for descriptive user surveys on socio-demographic variables, perceived quality and fulfillment of the therapeutic plan of TCs, as well as consumption patterns of patients from the TCs contacted and who were willing to continue participating in the study. The surveys were made by previously trained.

Patients eligible for the survey were those who had entered the TCs early 2009 or late 2012. The questionnaires used were translated to portuguese for the participants of Brazil, and adapted to each of the other countries in order to improve the reception of the user who were willing to participate in the study. These questionnaires were created by the group and were administered by previously trained representatives in each country.

The questions evaluating the perception of TCs from the users were scored from 1 to 5, 1 meaning completely unsatisfied and 5 completely satisfied. For the question of improvement perception the answers were also classified from 1 to 5 , being 1 not improvement and 5 totally improvement.

Additionally, a retrospective data gathering was carried out by applying surveys to the TCs directors, requesting information on drop outs, admissions and therapeutic discharges in the three years prior to the study. Except 3 Argentinian TCs that were selected and refused to provide the information requested, the rest did not object to deliver the required information. 
Table 1 De Leon criteria [18, 19]

\begin{tabular}{|c|c|}
\hline Component & Brief description \\
\hline Planned duration of the treatment & $\begin{array}{l}\text { The length of the treatment will be adjusted to the individual } \\
\text { needs of each patient. }\end{array}$ \\
\hline Alienation from the community & $\begin{array}{l}\text { In a residential context, the patients will be kept away from the exterior } \\
\text { community } 24 \mathrm{~h} \text { a day for at least some months, before acquiring privileges } \\
\text { of permit }\end{array}$ \\
\hline Community activities & $\begin{array}{l}\text { Excepting the individual counseling, all the activities are scheduled i community } \\
\text { with the other residents }\end{array}$ \\
\hline Staff roles and functions & $\begin{array}{l}\text { Independently of the professional function, each member has to fullfill the function } \\
\text { of community member. For this reason, the mission from each member of the staff } \\
\text { is to provide help and aids according to the method of community self-help }\end{array}$ \\
\hline Residents as role model & $\begin{array}{l}\text { The members who show expected conducts and capture the values, ideas and beliefs } \\
\text { of the community are used as role model for the other residents }\end{array}$ \\
\hline Structured day & $\begin{array}{l}\text { The activities are daily planned in order to distract de residents from their cravings, } \\
\text { thoughts about consumption and drugs, and also from the routine of their daily living }\end{array}$ \\
\hline Job as therapy and education & $\begin{array}{l}\text { According to the methodology of self-help, all the members are responsible of the daily } \\
\text { management of the facilities. The work is distributed among the users creating } \\
\text { responsibilities and duties with education and therapeutic goals }\end{array}$ \\
\hline A vision of recovery and right living & $\begin{array}{l}\text { There are some established concepts in the methods used by the Therapeutic community } \\
\text { to instruct about topics around the rehabilitation and drug cessation through the self-help } \\
\text { methodology }\end{array}$ \\
\hline Meeting groups between residents & $\begin{array}{l}\text { The common sense of conducting this kind of meeting is to create awareness in each } \\
\text { patient about patterns and attitudes related to the pattern of consumption that could be } \\
\text { identified sharing their experiences with other residents of the community }\end{array}$ \\
\hline Awareness training & $\begin{array}{l}\text { The main goal of all the therapeutic or educational is to increase self-awareness of the } \\
\text { individual about the consequences, impacts and repercussions of their previous conducts } \\
\text { and attitudes in themselves and in their social environment. }\end{array}$ \\
\hline Personal growth training & $\begin{array}{l}\text { To achieve this goal, the community should guarantee education and instructions to the } \\
\text { patient of how to identify their own feelings with their respective management and expression } \\
\text { in a constructive way and how to share them in community. }\end{array}$ \\
\hline Care continuity & $\begin{array}{l}\text { Fulfilling the treatment plan, with the goals of increasing self-awareness and change of their } \\
\text { vision based in the community and self-help method is the firs step. After this, a network } \\
\text { between the user and community should be established in order to keep the process of } \\
\text { continuous personal and growth and providing personal experiences to newcomers. }\end{array}$ \\
\hline
\end{tabular}

After obtaining all patient oral and written informed consent, questionnaires, and having collected the required information from the TCs directors, information was integrated into a Microsoft Excel database. The datasets used and/or analyzed during the current study is available from the corresponding author on reasonable request.

This study was conducted with according to the principles established by the 2000 Helsinki Declaration. The study also counted with the approval of the ethics and review board from each of the Universities or Institutions involved in the study.

\section{Results}

\section{Therapeutic communities selected and number of participant users}

In all, $58 \mathrm{TCs}$, with 1414 users were interviewed, though much of the information from users of TCs in Argentina was not complete and therefore not included in some analysis of sample data.

The country that provided more participant TCs was Brazil with 20 communities (34\%), and less involved was
Colombia with only 7 TCs (12\%). Most people interviewed were men, accounting for $92 \%$ of the surveyed sample, the most common marital status was single, accounting for $62 \%$ of the sample. Regarding employment status, $53 \%$ reported being employees prior to his admission to the TC, and $46 \%$ were unemployed. (See Table 2).

\section{Consumer age and previous hospitalization}

The age of first use of any non-alcohol PSs varied greatly across countries, being the lowest Mexico with first intake made at 4 years of age. As for the older age of first use of a substance, it was reported in Brazil with a report of 53 years of age. Unlike the consumption of younger and older age, the average age was very similar between different countries, generally averages between 15 and 16 years of age (see Table 3 ).

In terms of number of previous hospitalizations, 684 users $(65 \%)$ reported not having been previously hospitalized, 369 users (35\%) reported having been hospitalized at least once before, and 295 (28\%) responded that 
Table 2 Number of TCs surveyed by country and sociodemographic characteristics

\begin{tabular}{|c|c|c|}
\hline & $\mathrm{n}$ & $\%$ \\
\hline \multicolumn{3}{|c|}{ Participant TCs by country } \\
\hline$\square$ Argentina & 9 & 16 \\
\hline$\square$ Brazil & 20 & 34 \\
\hline$\square$ Colombia & 7 & 12 \\
\hline$\square$ México & 10 & 17 \\
\hline$\square$ Perú & 12 & 21 \\
\hline \multicolumn{3}{|c|}{ Interviewed users by country } \\
\hline$\square$ Argentina & 361 & 26 \\
\hline$\square$ Brazil & 300 & 21 \\
\hline$\square$ Colombia & 178 & 13 \\
\hline$\square$ México & 300 & 21 \\
\hline$\square$ Perú & 275 & 19 \\
\hline \multicolumn{3}{|l|}{ Gender } \\
\hline$\square$ Males & 1298 & 92 \\
\hline$\square$ Females & 116 & 8 \\
\hline \multicolumn{3}{|l|}{ Marital Status } \\
\hline$\square$ Single & 673 & 64 \\
\hline$\square$ Married & 168 & 16 \\
\hline$\square$ Divorced & 95 & 9 \\
\hline$\square$ Widower & 11 & 1 \\
\hline$\square$ Free Union & 95 & 9 \\
\hline$\square$ No Data & 11 & 1 \\
\hline \multicolumn{3}{|c|}{ Previous Work Activity ${ }^{a}$} \\
\hline$\square$ Employee & 558 & 53 \\
\hline$\square$ Unemployed & 484 & 46 \\
\hline$\square$ No Data & 11 & 1 \\
\hline
\end{tabular}

${ }^{a}$ Total number of patients was 1053, there was no data from Argentina

they had been interned three times before their current treatment.

\section{Substance use}

Users answered if they had consumed some substance different from alcohol in the 30 days prior to their stay in the TC, and identify the non-alcohol substance used. The results across countries are similar, being marijuana the most frequently (49\%), followed by cocaine (41\%) and basuco (cocaine base paste, possibly mixed with

Table 3 Age at first use of substances

\begin{tabular}{clllll}
\hline & Brazil & Colombia & México & Perú & Total \\
\hline Age $^{\mathrm{a}}$ & $\mathrm{n}$ & $\mathrm{n}$ & $\mathrm{n}$ & $\mathrm{n}$ & $\mathrm{n}$ \\
Minimum & 5 & 7 & 4 & 8 & 6 \\
Maximum & 53 & 45 & 46 & 48 & 48 \\
Average & 16,1 & 16 & 15 & 16 & 16 \\
\hline
\end{tabular}

${ }^{\mathrm{a}}$ There was no data from Argentina unknown components) users (28\%). Among the substances less reported are heroin powder (3\%) and dick (2\%) (Liquid used for cleaning machines). (See Fig. 1).

Also inquiring among users of alcohol consumption in the last six months, asking about how many times in that period, if had consumed more than 4 drinks if it was a woman, or more than 5 if it was male, in one day. $21 \%$ of respondents said no, $18 \%$ once, $60 \%$ more than once and $1 \%$ of respondents did not answer the question.

\section{User satisfaction survey}

The user satisfaction questionnaire evaluated several areas, such as admission, information on the TCs' internal rules, satisfaction with institution staff, as well as the improvement perception.

The first aspect evaluated (including reports from Argentinian TCs), was the complexity of TCs' admission process by patient, which according to most respondents (76\%) were slightly or not complicated. In addition, $88 \%$ of respondents reported that the staff explained to them in detail the institution rules and $68 \%$ of users reported being satisfied with the attention time spent by medical personnel (See Table 4). The following data (not including reports from Argentina) provides information about satisfaction with TCs' staff, including psychiatrists, psychologists, nurses and other personnel. 76\% were satisfied with the staff's work at the institution.

Less than $2 \%$ of users interviewed perceived little or no improvement in their underlying conditions, this being a constant in most countries. Most TCs users perceived improvement in their substance use problem, represented by $54 \%$ of respondents, showing that the users that participated in the study were perceiving some kind of improvement of their drug addiction without the use of other therapies like drug replacement therapy or an intense psychiatric management (see Table 5).

\section{TCs essential elements}

Compliance with quality indicators and essential elements in the sample selected of TCs were evaluated, which included "organized and standardized treatment programs", "family involvement in the treatment plan", "self-assessments of the therapeutic team", etc. (Other evaluated indicators, see Table 6). Most managers reported meeting almost all the criteria, however, the only country where all interviewed TCs met $100 \%$ of the items was Mexico. In Colombia, the least met indicators were "work as part of the therapeutic program" (71\%) and "users are encouraged to "act as if" to develop a more positive attitude" (71\%).

In Brazil, the element with the lowest compliance was "requesting professional qualifications to former addicts" this mean that if a former addict wanted to be an employ of the therapeutic community, he was not asked 


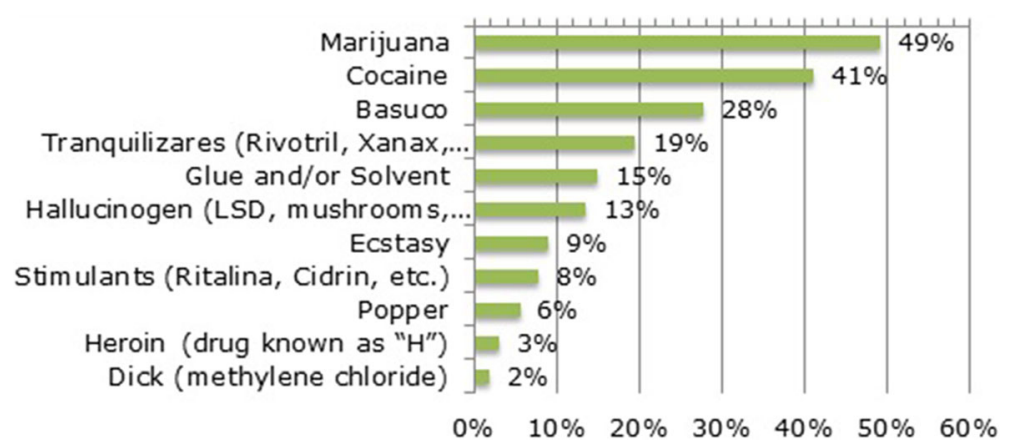

Fig. 1 Most consumed substances in the participating countries except Argentina

about any degree or professional qualification in order to be a worker in the TC.In Peru, the lowest score was the criterion of "The therapeutic program includes training in personal decision-making and social skills". In Argentina, despite the quality indicators were not met by all communities, there was no indicator to be less satisfied compared to the rest.

\section{Retrospective data collection}

Data and medical records of the TCs who agreed to participate (including details of admission and discharge of patients in the time period between the second half of 2009 and the first six months of 2012) were gathered. Should be clear that in this retrospective collection, data from the Argentinian participating institutions was not obtained. Records of 3461 patients were obtained, of which $87 \%$ were male and $13 \%$ female. The ages of the individuals had a wide range between 13 to 79 years, with an average of 30 years, showing the variability of people who suffer from drug addictions.

The main reasons for abandonment were collected. A total of 1453 records(42\%) were analyzed, in which the most frequent were "not feeling comfortable with the

Table 4 User satisfaction

\begin{tabular}{lll}
\hline & N & $\%$ \\
\hline Admission Process & & \\
$\square$ Not Complicated & 785 & 56 \\
$\square$ Slightly Complicated & 287 & 20 \\
$\square$ Very Complicated & 64 & 4 \\
$\square$ Quite Complicated & 50 & 4 \\
$\square$ Have not participated in admission process & 228 & 16 \\
Time spent by the doctor & & \\
$\square$ Enough & 959 & $68 \%$ \\
$\square$ Not Enough & 455 & $32 \%$ \\
Information on the TCs' internal rules & & \\
$\square$ Yes & 1258 & $89 \%$ \\
$\square$ No & 156 & $11 \%$ \\
\hline
\end{tabular}

institution" (31\%), followed by "ignorance of the cause" (27\%) and "lack of family support" (20\%). Less frequent reasons were "not feeling comfortable with the institution's staff" (1\%) and "have not perceived any improvement” (2\%) (See Fig. 2).

To analyze the reasons for patients discharge, 3461 individuals' data was obtained, of which $44 \%$ were therapeutic discharge, i.e. completion of the treatment plan, and $42 \%$ withdrew. For the remaining $14 \%$, no data was obtained. Finally, follow-up at one year of 795 patients main activity was collected, of which the vast majority (51\%) was working, $25 \%$ were studying, $14 \%$ were unemployed, $10 \%$ did not know and $2 \%$ do not have the data (Fig. 3). The vast majority of these (71\%) were conducted by telephone communication, followed by visiting the TCs (23\%) and the remainder is distributed among contact via e-mail or home visit.

\section{Discussion}

The findings of this study are the first in Latin America allowing adequate description of the TCs in our region with a high amount of the user reporting a quite to totally improvement just with this intervention. It is the first study in this part of the world, and including five countries allows proper identification of these institutions and regulates in a more uniform manner its existence. This could help to the establishment of more rules and guidelines to unify and standardized the care delivered by this type of institutions.

Table 5 Improvement perception reported by users

\begin{tabular}{|c|c|c|c|c|c|c|c|c|c|c|}
\hline & \multicolumn{2}{|c|}{ Brazil } & \multicolumn{2}{|c|}{ Colombia } & \multicolumn{2}{|c|}{ México } & \multicolumn{2}{|c|}{ Perú } & \multicolumn{2}{|l|}{ Total } \\
\hline & $n$ & $\%$ & $\mathrm{n}$ & $\%$ & $\mathrm{n}$ & $\%$ & $n$ & $\%$ & $n$ & $\%$ \\
\hline tally & 83 & 29 & 68 & 38 & 52 & 16 & 55 & 20,0 & 258 & 25 \\
\hline Quite & 153 & 53,5 & 85 & 48 & 195 & 59,8 & 139 & 50,6 & 572 & 54 \\
\hline me & 32 & 11,2 & 23 & 13 & 71 & 21,8 & 58 & 21,0 & 184 & 17 \\
\hline ittl & 13 & 4,5 & 2 & 1 & 5 & 1,5 & 6 & 2,2 & 26 & 2 \\
\hline t & 5 & 1,7 & 0 & 0 & 3 & 0,9 & 6 & 2,0 & 14 & 1 \\
\hline
\end{tabular}

There was no data from Argentina 
Table 6 Indicators compliance by the TCs

\begin{tabular}{|c|c|c|c|c|c|c|c|c|c|c|c|c|}
\hline & \multicolumn{2}{|c|}{ Argentina } & \multicolumn{2}{|c|}{ Brazil } & \multicolumn{2}{|c|}{ Colombia } & \multicolumn{2}{|c|}{ México } & \multicolumn{2}{|c|}{ Perú } & \multicolumn{2}{|c|}{ Total } \\
\hline & $\mathrm{n}$ & $\%$ & $\mathrm{n}$ & $\%$ & $n$ & $\%$ & $n$ & $\%$ & $n$ & $\%$ & $\mathrm{n}$ & $\%$ \\
\hline $\begin{array}{l}\text { The therapeutic program includes training in personal } \\
\text { decision-making and social skills }\end{array}$ & 9 & 100 & 20 & 100 & 7 & 100 & 10 & 100 & 8 & 67 & 54 & 92 \\
\hline $\begin{array}{l}\text { Recovery means for TC development of personal identity } \\
\text { and global change lifestyle }\end{array}$ & 9 & 100 & 20 & 100 & 7 & 100 & 10 & 100 & 12 & 100 & 59 & 100 \\
\hline Users learn conflict resolution skills & 9 & 100 & 20 & 100 & 7 & 100 & 10 & 100 & 11 & 92 & 58 & 98 \\
\hline The work is part of the therapeutic program & 8 & 88 & 20 & 100 & 5 & 71 & 10 & 100 & 12 & 100 & 55 & 93 \\
\hline $\begin{array}{l}\text { Users are encouraged to "act as if" to develop a more } \\
\text { positive attitude }\end{array}$ & 9 & 100 & 19 & 95 & 5 & 71 & 10 & 100 & 11 & 92 & 55 & 93 \\
\hline $\begin{array}{l}\text { Regularly seminars are held to help residents find a balance } \\
\text { between the emotional and cognitive experiences of the } \\
\text { TC program }\end{array}$ & 8 & 88 & 19 & 95 & 6 & 86 & 10 & 100 & 12 & 100 & 56 & 95 \\
\hline Requesting professional qualifications to former addicts & 8 & 88 & 10 & 50 & 6 & 86 & 10 & 100 & 11 & 92 & 45 & 76 \\
\hline Advisory services are provided to the user's family & 9 & 100 & 20 & 100 & 7 & 100 & 10 & 100 & 12 & 100 & 59 & 100 \\
\hline $\begin{array}{l}\text { The TC has medical records and individual records for } \\
\text { monitoring and continuous evaluation of services }\end{array}$ & 9 & 100 & 19 & 95 & 7 & 100 & 10 & 100 & 12 & 100 & 58 & 98 \\
\hline $\begin{array}{l}\text { The TC has guidelines for developing an institutional climate } \\
\text { of trust and mutual support; It has a written declaration of } \\
\text { user's rights and duties }\end{array}$ & 9 & 100 & 20 & 100 & 7 & 100 & 10 & 100 & 12 & 100 & 59 & 100 \\
\hline $\begin{array}{l}\text { There is a flowchart of the TC's staff functions, which are known } \\
\text { and accepted by all }\end{array}$ & 9 & 100 & 20 & 100 & 7 & 100 & 10 & 100 & 12 & 100 & 59 & 100 \\
\hline $\begin{array}{l}\text { The TC periodically performs an assessment of its effectiveness } \\
\text { and efficiency, which includes user's review and satisfaction }\end{array}$ & 8 & 88 & 19 & 95 & 7 & 100 & 10 & 100 & 9 & 75 & 53 & 89 \\
\hline
\end{tabular}

One of the first findings in our study was that up to $90 \%$ of the respondents were men, which may be because the male are more likely to consume PSs compared with women, as issued in 2014 by the UNODC report [20]. Additionally, in a study conducted by Johnson et al. in Thailand, in which they evaluated 22 TCs, most users were men [21]. The sexism or Macho culture spread through all Latin America also could explain the greater proportion of male assisting to this communities because of the Taboo or bad image that this can cause in a woman.

Another finding of our study was that most users of the TCs interviewed were single before admission to the program. These findings are similar to those found by studies such as Fernández- Montalvo [22], in which 72\% of respondents were single, while in other studies such as Sadir et al. [23] only $48 \%$ were single. In our study, the majority of respondents (53\%) were employed before entering the institution, however, reports of employment status among TCs users are highly variable with employment rates of only 17\% in one TC in Australia [24], or as high as $64 \%$ in Iran . One explanation of these differences may be that in the countries were the study was conducted, most of the TCs are private or belong to a religion and not public and supported by the government. This would make the entrance to this center more difficult because some patients do not have the money or resources to access them.

The average age of first use of a non-alcohol psychoactive substance was 16.1 on average for the entire

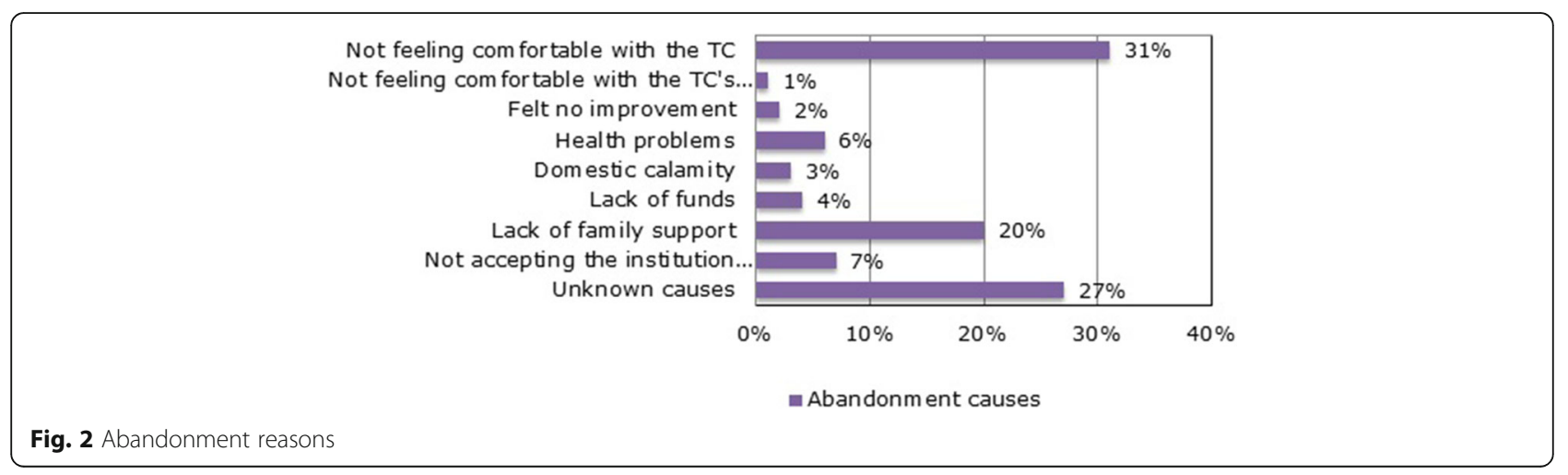




\section{Actual activity}

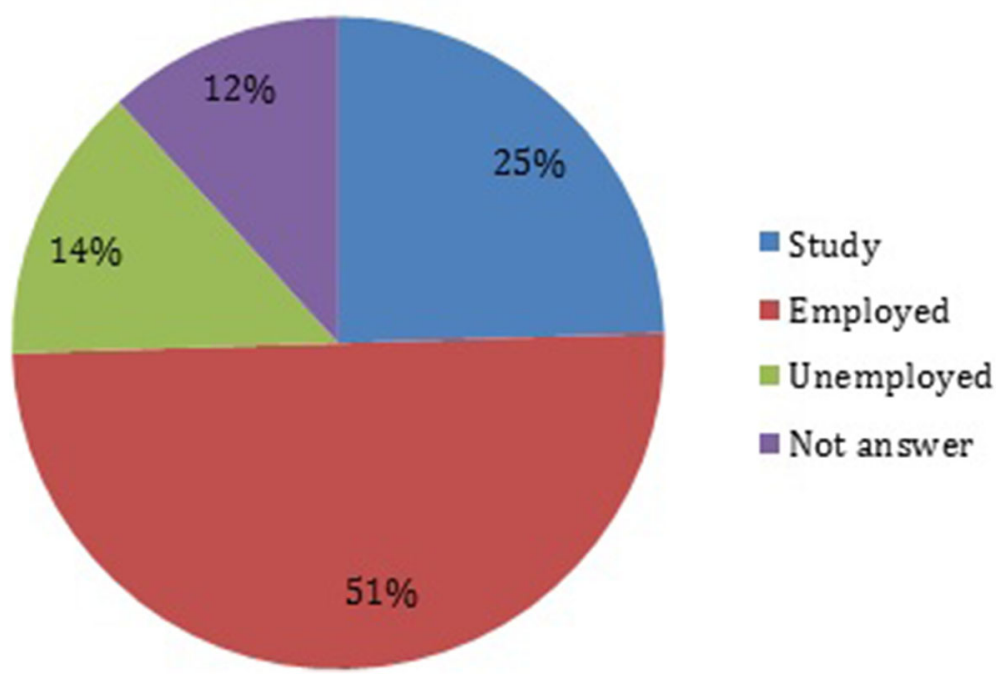

Fig. 3 Actual activities of the user who ended their treatment plan

sample, a value that is similar to those found in other studies for different countries in the region [25] and as reported by the UNODC [20]. Most patients in our sample $(68 \%)$ had not reported any previous attempt of entry into a TC, and only $28 \%$ reported to have entered more than three times; these figures differ from those reported by a study in Iran [23] in which only $25 \%$ of respondents had less than two entry attempts to a TC facility and $75 \%$ had three or more attempts of entering TCs for treatment. Another study conducted by Darke [24] and colleagues found that up to $58 \%$ of patients interviewed had been admitted at least once in a TC treatment .

The non-alcohol substance most frequently consumed in the last 30 days was marijuana, followed by cocaine and basuco (cocaine base), but as mentioned earlier in this article, the epidemiology of substances consumed varies depending on the region. In a study in Thailand, the substances most frequently consumed in the same period were stimulants (ecstasy, speed, ice), followed by inhalants and marijuana [21]. The study by Darke [24] et al., found that the most commonly used drugs in the last six months were benzodiazepines, followed by marijuana and heroin.

The difficulty of getting admission of patients to the TCs was evaluated by patients as slightly or not complicated showing that the main reasons for not using this kind of treatment for substance use are not related to the procedure related to the admission to the community; these results were similar to those found in the study of López- Goñi et al. [26], who found that most of the interviewees reported that the entrance to the TCs was simple. Another aspect evaluated that was not seen in other references, was the user satisfaction with medical care and the health team. $68 \%$ of users are satisfied with the care given time, this may be because the patients who accept to go to the TCs hope that if they are going to be intern in a drug-free residence their health should be more supervised than in other places.

Up to $79 \%$ of respondents perceived that they had had enough or complete improvement in their condition with the entrance to the TC, and less than $2 \%$ did not feel any improvement. These findings are different from those reported by Fernandez et al. [22], who found that only $54 \%$ of users had perceived some degree of improvement and $46 \%$ had not felt any improvement or deterioration in his health. These could be explained by differences in the users or the number of sample that had each of the studies. Other reasons may be how the improvement was evaluated if just by asking the patient or following them until they relapse or how long was the period of abstinence. These differences mainly exist because there are no standardized measures of treatment success of substance use which could limit the comparisons between the results of different studies about management of drug addictions. Another explanation could be the selection bias because only users who were active in the program were interviewed, but not those who abandoned the program. All these explanations could modify the proportion of users feeling any improvement in their condition.

Evaluation of TCs' quality indicators evidenced that Latin America meet most of the criteria, however, the criteria "requesting professional qualifications to former 
addicts" and "use the work as part of the treatment plan", were lower compliance indicators. Although there are no studies that have used the same criteria we employed, there is another tool to assess the quality of the TCs, known as SEEQ. This questionnaire contains 139 questions and it is narrowed to evaluated 6 dimensions of the TCs in a likert-type questions from 1 (very little importance) to 5 (extremely important) and is directed to the directors and staff of the community [27].

SEEQ was used in the Goethal et al. [17]study, in which traditional and modified TCs were evaluated in Europe and USA. Among the findings of this study they come upon that the criteria elements with lower scores in European TCs were "process monitoring and evaluation of its programs", and "ranking TCs staff members using an established organization chart". As for the US TCs, the worst scores were achieved in the fields of confrontation and psychological problems arising from drug use as well as family integration in user's treatment.

The proportion of therapeutic discharges and abandonments are very similar ( $44 \%$ and $42 \%$ ), these data being different to studies in Australia [24] and Thailand [21], where $17 \%$ and $33 \%$ of departures ended in abandonment and $34 \%$ and $66 \%$ in therapeutic discharges respectively. The main reasons for abandonment in our study were "not feeling satisfied with the institution", "unknown reason" and "lack of family support", being compared with another study by López- Goñi et al. [26] agrees that the single most frequent reason for abandonment is "not feeling comfortable with the institution". This finding points out a key question and problem of the TCs designs and how its principles are being adopted by different institutions to make comfortable their users. This issue could be starting point in the design and conduction of new studies to reduce this percentage of users not feeling comfortable with the TCs.

Close monitoring to some users, found that most of the patients were working or studying, and their activities were unknown in $10 \%$ of this sub-sample. These findings were also found in a longitudinal study in Spain [22], in which it was found that most users of the evaluated TC, whether they had completed treatment or not, were working. Despite these results, we can not generalize it because of the small sub sample of user that were followed that represented less than $50 \%$ of the evaluated users.

The collaboration of several Latin American countries, along with the large sample collected of TCs and users, are the greatest strengths of our study, allowing to find the differences between the TCs available in the countries, the most consumed substances, the consumption onset age and other variables that allow to find out the quality of TCs among the studied countries and an estimate of the services available in our region. Most of the finding of our study are consistent with previous reports of the literature, but with the findings of the high satisfaction rate and the fulfillment of the essential criteria of the TCs it opens new doors in order to propose this method as an alternative for the management of drug addictions.

One of the weaknesses, was selecting centers that have fulfilled a minimum score in the first phase of the study, because this could have biased the interpretation of variables as the fulfillment of essential elements of quality, as may have limited the selection of center users to those with better qualifications, thereby reducing the possibility of extrapolating the findings of our study. Another major limitation of both the study and participating centers was the high proportion of missing information on variables as the length of stay of the patients, "reasons for abandonment", monitoring and discharges during the period in which the study was conducted. Selection bias could have modified the results because only active users were interviewed for the satisfaction and improvement status, but users who already fulfilled their treatment plan were not contacted.

\section{Conclusion}

TC's are one of the therapeutic options for the treatment of patients with substance use disorder, so the findings of this study showed that the participating TCs fulfilled the minimum quality criteria to provide management to the patients and most of the patients are satisfied with the received treatment. Despite, there is still room to improve, especially in the follow up of the patients in order to provide more complete data about the effectiveness of this interventions in the patient in Latin America.TCs are also widespread in the region and the knowledge of how are they performing and their quality may allow them to be more popular among the people of the region and the governments.

\section{Abbreviations}

HIV: Human Immunodeficiency Virus; LAFCT: Latin American Federation of Therapeutic Communities; NMHS: National Mental Health Survey; PSs: Psychoactive substances; TCs: Therapeutic Communities; UNODC: United Nations Office on Drugs and Crime; WHO: World Health Organization; YLL: Years of life lost

\section{Acknowledgments \\ Special thanks to Brazilian Federation of Therapeutic Communities (FEBRACT), Colombian Federation of Therapeutic Communities (FECCOT), State Council Against Addictions in Jalisco (CECAJ), Mexican Federation of Therapeutic Communities (FEMEXCOT) Developing Life without Drugs (DEVIDA) by the Peruvian Ministry of Health $(\mathrm{MOH})$, Peruvian Association of Therapeutic Communities (PTCA), Centre for Information and Education for the Prevention of Drug Abuse (CEDRO), Argentine Drug Observatory (SEDRONAR), the Latin American Federation of Therapeutic Communities (FLACT) and doctor Manish K. Mishra.}

\section{Funding}

This study was financially supported by: Corporative Foundations, A.C, USA embassy in Peru, Bancolombia group S.A. 


\section{Availability of data and materials}

The datasets used and/or analysed during the current study available from the corresponding author on reasonable request.

\section{Authors' contributions}

CG: The general coordinator in charge of retrieving and condensation the data from the five countries and was the main investigator in Colombia. Also was in charge of supervising the redaction of the manuscript. PM and RR: Co-investigators who retrieved the data from the Colombian therapeutic communities and compiled the results after the data was evaluated by the statistician from the group. Actively participated in the elaboration of the manuscript. NR: Was in charge of the design of the database with the posterior depuration and analysis of the data from the 5 countries. ME and RG: Main Investigators from Argentina who conducted the survey and retrieved the data from the Argentinian therapeutic Communities. MA and AS: Main Investigators from Brazil who conducted the survey and retrieved the data from the Brazilian therapeutic Communities. JC and JG: Main Investigators from Mexico who conducted the survey and retrieved the data from the Mexican therapeutic Communities. MF and DW: Main Investigators from Peru who conducted the survey and retrieved the data from the Peruvian therapeutic Communities. All authors read and approved the final manuscript.

\section{Ethics approval and consent to participate}

This study was conducted according to the Helsinki declaration and obatained approval from each of the institutions participating in the study. Also, verbal and written consent from each of the patients was obtained.

\section{Consent for publication}

Not applicable.

\section{Competing interests}

The authors declare that they have no competing interests.

\section{Publisher's Note}

Springer Nature remains neutral with regard to jurisdictional claims in published maps and institutional affiliations.

\section{Author details}

'Department of Clinical Epidemiology and Biostatistics, Hospital Universitario San Ignacio, Pontificia Universidad Javeriana, Bogota, Colombia. ${ }^{2}$ School of Medicine, Pontificia Universidad Javeriana, Bogota, Colombia. ${ }^{3}$ Unity of Epidemiological Studies in Mental Health, Psychology Faculty, National University of Cordoba, Cordoba, Argentina. ${ }^{4}$ Department of Psychiatry, Federal University of São Paulo (UNIFESP), São Paulo, Brazil. ${ }^{5}$ Consejero Terapéutico State Council Against Addictions, Guadalajara, Jalisco, Mexico. ${ }^{6}$ Polymetrix, Cabo San Lucas, Jalisco, Mexico. 7 Universidad Peruana Cayetano Heredia, Lima, Perú. ${ }^{8}$ National Institute of Public Health, Lima, Peru.

Received: 14 May 2017 Accepted: 16 October 2017 Published online: 20 December 2017

\section{References}

1. Caulkins JPPD, Kasunic AMS, Lee MACMS. Societal burden of substance abuse. Int. Public Health J. 2014;6:269-82.

2. Observatorio argentino de drogas. Estudio de costos del abuso de sustancias psicoactivas en la Argentina. Argentina: Buenos Aires; 2007.

3. Observatorio peruano de drogas. Estudio del impacto social y económico del consumo de drogas en el Perú. Lima. In: Perú; 2010.

4. National Institute of Drug Abuse (NIDA). Drugs, Brains, and Behavior the science of addiction [Internet]. United States; 2010 [cited 2015 Jun 16]. Available from: https:/www.drugabuse.gov/publications/drugs-brains-behavior-scienceaddiction/preface

5. Ferrando SJ, Freyberg Z. Neuropsychiatric aspects of infectious diseases. Crit Care Clin. 2008;24:889-919. x

6. Schulden JD, Lopez MF, Compton WM. Clinical implications of drug abuse epidemiology. Psychiatr Clin North Am. 2012;35:411-23.

7. WHO International Consortium. In psychiatric epidemiology. Cross-national comparisons of the prevalences and correlates of mental disorders. Bull World Health Organ. 2000;78:413-26.
8. Whiteford HA, Degenhardt L, Rehm J, Baxter AJ, Ferrari AJ, Erskine HE, et al. Global burden of disease attributable to mental and substance use disorders: findings from the global burden of disease study 2010. Lancet. 2013;382:1575-86.

9. Instituto Nacional sobre el Abuso de Drogas, Departamento de Salud y Servicios Humanos de los EE.UU. Principios de tratamientos para la drogadicción. Una guía basada en las investigaciones [Internet]. Estados Unidos; 2010 [cited 2015 Jun 4]. Available from: https://www.drugabuse. gov/sites/default/files/podatsp.pdf

10. De Leon $\mathrm{G}$, editor. Community as method: therapeutic communities for special populations and special settings. Westport, Conn: Praeger; 1997.

11. World Federation of Therapeutic Communities (WFTC). What is a Therapeutic Community? [Internet]. Estados Unidos; [cited 2015 Jun 5]. Available from: http://www.wftc.org/therapeutic_community.html

12. Smith LA, Gates S, Foxcroft D. Therapeutic communities for substance related disorder. Cochrane Database Syst Rev. 2006:CD005338.

13. Johnson K, Pan Z, Young L, Vanderhoff J, Shamblen S, Browne T, et al. Therapeutic community drug treatment success in Peru: a follow-up outcome study. Subst Abuse Treat Prev Policy. 2008;3:26.

14. Fiestas F, Ponce J. Eficacia de las comunidades terapéuticas en el tratamiento de problemas por uso de sustancias psicoactivas: una revisión sistemática. Rev. perú. med. exp. salud. Publica. 2012;29:12-20.

15. Vanderplasschen W, Colpaert K, Autrique M, Rapp RC, Pearce S, Broekaert E, et al. Therapeutic communities for addictions: a review of their effectiveness from a recovery-oriented perspective. ScientificWorldJournal. 2013;2013: 427817.

16. Hubbard RL, Craddock SG, Anderson J. Overview of 5-year followup outcomes in the drug abuse treatment outcome studies (DATOS). J Subst Abus Treat. 2003;25:125-34.

17. Goethals I, Soyez V, Melnick G, De Leon G, Broekaert E. Essential elements of treatment: a comparative study between European and American therapeutic communities for addiction. Subst. Use Misuse. 2011;46:1023-31.

18. De Leon G. Therapeutic communities for addictions: a theoretical framework Int J Addict. 1995;30:1603-45.

19. De Leon G. The therapeutic community: theory, model, and method. New York: Springer Pub; 2000

20. United Nations Office on Drugs and Crime. World drug report 2014 [Internet]. 2014 [cited 2015 Jul 7]. Available from: http://www.unodc.org/ documents/wdr2014/World_Drug_Report_2014_web.pdf

21. Johnson KW, Young L, Shamblen S, Suresh G, Browne T, Chookhare KW. Evaluation of the therapeutic community treatment model in Thailand: policy implications for compulsory and prison-based treatment. Subst Use Misuse. 2012;47:889-909.

22. Fernández-Montalvo J, López-Goñi JJ, Illescas C, Landa N, Lorea I. Evaluation of a therapeutic community treatment program: a long-term follow-up study in Spain. Subst. Use Misuse. 2008:43:1362-77.

23. Sadir N, Shojaei M, Moadab K, Abbasi R, Bahrampour A, Nakhaee N. Outcome evaluation of therapeutic community model in iran. Int J Health Policy Manag. 2013;1:131-5.

24. Darke S, Campbell G, Popple G. Retention, early dropout and treatment completion among therapeutic community admissions. Drug Alcohol Rev. 2012;31:64-71.

25. Ministerio de Justicia y del Derecho - Observatorio de Drogas de Colombia, Ministerio, de Salud y Protección Social. Estudio Nacional de Consumo de Sustancias Psicoactivas en Colombia 2013- Informe Final. Bogotá. Colombia: ALVI Impresores S.A.S; 2014.

26. López-Goñi JJ, Fernández-Montalvo J, Illescas C, Landa N, Lorea I. Razones para el abandono del tratamiento en una comunidad terapéutica. Trastor Adict. 2008;10:104-11.

27. Melnick G, De Leon G. Clarifying the nature of therapeutic community treatment. The survey of essential elements questionnaire (SEEQ). J Subst Abus Treat. 1999;16:307-13. 